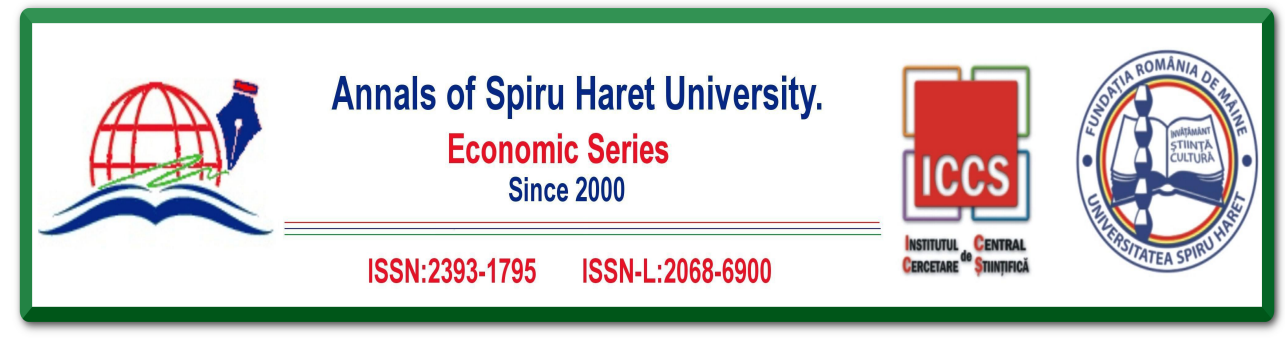

Issue 3/2019

\title{
JOB DESIGN AND EMPLOYEE PERFORMANCE IN NIGERIA BOTTLING COMPANY PLC, BENIN CITY
}

\author{
Moses M. ADAGBABIRI ${ }^{1}$, Ugo Chuks OKOLIE ${ }^{2}$ \\ ${ }^{1}$ Department of Political Science, Delta State University, Abraka, \\ Tel.: 08033929964, Email: adagbabirimoses@gmail.com \\ ${ }^{2}$ Chartered Institute of Personnel management of Nigeria \\ Edo State Study centre, Benin City, Tel.: 08063499170, \\ Email: ugookolie3@gmail.com
}

How to cite: ADAGBABIRI, M.M. \& OKOLIE, U.C. (2019). "Job Design and Employee Performance in Nigeria Bottling Company Plc, Benin City." Annals of Spiru Haret University. Economic Series, 19(3), 65-89, doi: https://doi.org/10.26458/1934

\section{Abstract}

Job design and employee performance are two concepts that are of significance to all modern corporate entities. A robust appreciation and application of these concepts will contribute in measurable respects to the growth and sustainability of various organizations. This study is an assessment of the impact of job design on employee performance in Nigerian Bottling Company Plc, Benin City. A descriptive method was adopted and data was collected via a survey of 237 respondents. The study found that job design which comprises job rotation, job enlargement and job enrichment has a positive correlation with employee performance. Requisite conclusion and recommendations were provided in the light of empirical and theoretical findings.

Keywords: job design; employee performance; job characteristics.

JEL Classification: J01, J24 


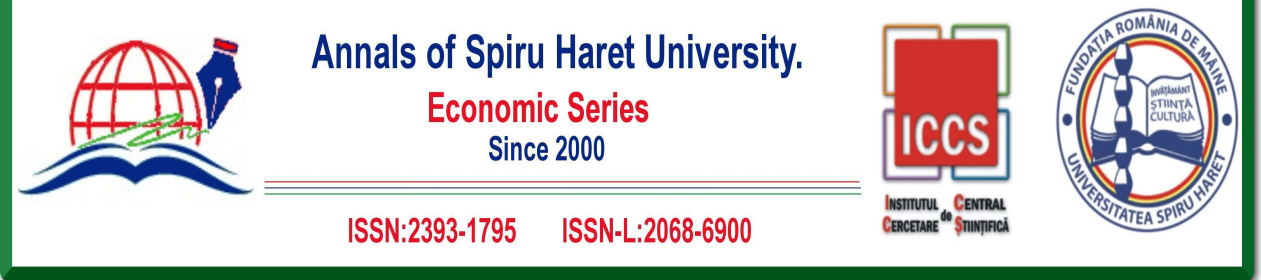

Issue 3/2019

\section{Introduction}

Job design is an outgrowth of job analysis that improves jobs through technological and human considerations in order to enhance organization efficiency and employee job satisfaction. It is concerned with changing, modifying, and enriching jobs in order to capture those talents of employees while improving organization performance [Bohlander \& Snell, 2007]. Job design has been one of the most effective tools used for optimizing an employee's performance. Effective job design is measure of the degree to which the employee is involved in his/her tasks and assignments. Bates (2004) posits that an effective job design brings involvement of an employee in work related activities which clearly forecasts employee output, departmental productivity and organizational success. Therefore, organizations which are engaged in continuous improvement, or process reengineering, may revamp their jobs in order to eliminate unnecessary job tasks or find better ways of performing work. Job design should facilitate the achievement of organizational objectives. At the same time, the design should recognize the capabilities and needs of those who are to perform the job.

In Nigeria context, the evolvement of jobs in the past was not planned. The practice was for the supervisor or foreman to assign workers to tasks and to randomly group tasks into jobs. For instance, like carpentry, iron bending, electrical work, the content of each trade evolved through tradition and by initiation. However, psychological literature on employee motivation holds claims that the design of work, its content and structure affect both productivity and employee morale [Onimole, 2015]. Therefore, there have been many theories and approaches to the design of jobs. An early reaction to the scientific management philosophy of fitting men to machines was the endeavour of human relations advocates to meet worker's social needs in the workplace, while doing little about the nature of the work itself. However, with the increasing recognition of the complexity of human motivation, not few modern theorists have argued that specialized and simplified work leads to monotony, boredom and general dissatisfaction, which as a result, manifest themselves in various forms of undesirable work behaviour in terms of lateness, absenteeism, and often job changes. The application of these theories to the design of job has produced a multitude of measures concerned with altering the content of job and its organization, thus reversing the job specialization trend by adding more varied tasks and broader responsibilities [Hepworth, 1982]. However, in an attempt to reduce boredom and therefore increase job satisfaction, some techniques of job design have been procreated. These techniques include job rotation, job enlargement and job enrichment. 


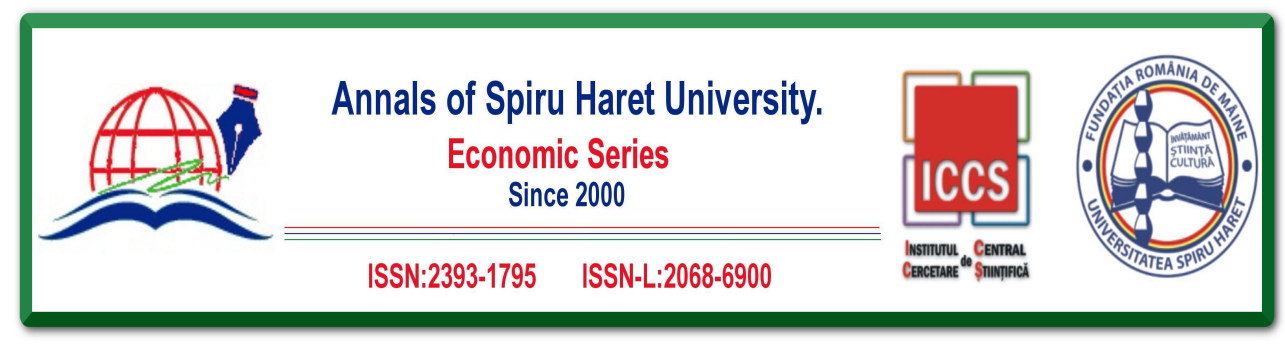

Issue 3/2019

In Nigeria, however, job design remains a topic that receives much less attention from employers and policy makers as a driver of employee's performance compared with other aspects of management such as leadership or management style. Also, results of studies from developed countries to developing countries have been time and again showing that job design practices have significant impact on employee performance [Herzberg, 1966; Hackman \& Oldham, 1976; Parker, 1998; Grant, 2008; Zareen \& Razzaq, 2013; Syarifah, 2013; Achieng et al., 2014; Ali \& Zia-urRehman, 2014; Parker, 2014; Siruri \& Muathe, 2014; Onimole, 2015; Parker et al., 2017]. But unfortunately little empirical research has been conducted to examine the impacts of job design practices on employee performance in Nigeria. This study has been undertaken to augment the contemporary knowledge base of human resource management practices of developing countries.

\section{Statement of the Problem}

Employees in every organization want to draw fulfilments from their jobs and every human resource managers/management wants the employees to be fulfilled being the most important resources of the organization but managers for ages have been struggling on how to make them get the fulfilment [Magaji, 2014]. Globalization has created many challenges for multinational and local organizations such as cost of production that is on the increase day-by-day due to universal factors such as world recession, resource limitation, information technology and trends that have affected the way work is done and also changed the face of competition among organizations. The problem of job design stemmed from the fact that in today's competitive environment, organizations globally want to maximize the potential of their human resources to stay ahead of the aggressive competition in the middle of the quest [Nanle, 2015]. The problems of boredom and job dissatisfaction which consequently result in employee's low productivity, absenteeism and lateness, work stress, delay in administrative performance, psychological breakdown and eventually withdrawal of services are common decimal in most organizations. One possible reason for this development is that employees in these organizations view their jobs as dead ends and therefore have no pride in their jobs [Parker et al., 2017]. To prevent losing such valuable workforce to competitors as a result of boredom and job dissatisfaction, Achieng et al. (2014) stated that job design and redesign could be an excellent means.

Job design and employee's attitude towards job design has become an issue of great concern in the recent years among many organization but it has been rarely 


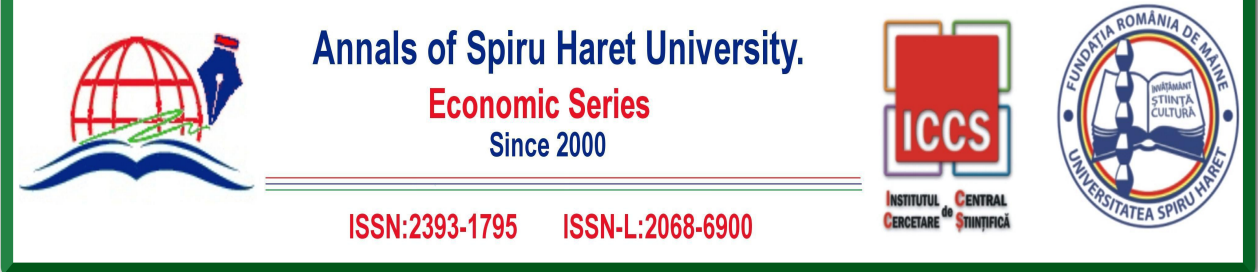

\section{Issue 3/2019}

studied in academic literature in developing countries and there is a lack of awareness about its effects and its antecedent. Therefore, this study was conducted to examine the impact of job design on employee performance. It also investigated the relationship between the components of job design and employee performance in Nigeria Bottling Company Plc, Benin City. It is to this end that this study raised the following research questions:

i. Is there any significant relationship between job rotation and employee performance in Nigerian Bottling Company Plc, Benin City?

ii. Is there any significant relationship between job enlargement and employee performance in Nigeria Bottling Company Plc, Benin City?

iii. Is there any significant relationship between job enrichment and employee performance in Nigeria Bottling Company Plc, Benin City?

\section{Significance of the Study}

This study was conducted to determine how employee performance could be improved through job design. Hence, this research work would stimulate the interest and awareness of the management of Nigerian Bottling Company Plc, Benin City of the need to apply components of job design as additional motivational tool to stimulate the performance of their employees. The study would also provide alternative motivational strategy to management of both private and public enterprises, mangers, and other who use human resources as an important input in their operational activities. Finally, the study will provide a building block and therefore serve as a strong reference point for future researchers, academia, and students of management and social sciences who may deem it fit to carry out further studies on the subject matter.

\section{Literature Review}

\section{The Concept of Job Design}

Before we proceed, it is important to define job. A typical definition of a job is "an aggregation of tasks assigned to a worker" [Parker et al., 2017]. Bohlander and Snell (2007) also posited that a job consists of a group of related activities and duties. Ideally, the duties of a job should consist of natural units of work that are similar and related. They should be clear and distinct from those of other jobs to minimize misunderstanding and conflict among employees and to enable employees to recognize what is expected of them. From this perspective, job design refers to "the 68 


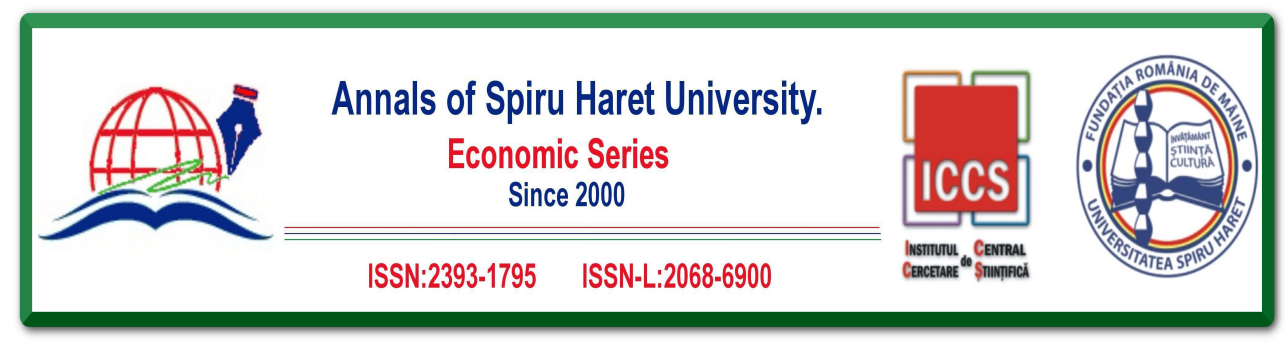

Issue 3/2019

content and organization of tasks" [Parker et al., 2017]. Similarly, Armstrong (2009) posited that job design specifies "the contents, methods, and relationships of jobs in order to satisfy work requirements for productivity, efficiency and quality, meet the personal needs of the job holder and thus increase levels of employee engagement". Also, Parker (2014) defines work design as "the content and organization of one's work tasks, activities, relationships, and responsibilities", and Opatha (2002) considers job design to include "the functions of arranging tasks, duties and responsibilities into an organizational unit of work". Al-Badarin and Al-Azzam (2017) added that job design leads to job satisfaction by increasing the level of responsibilities and giving the sense of freedom, autonomy and opportunity for employees to decide what and how the job is to be performed and accomplished.

Job design involves the planning of the job including its contents, the methods for performing the job, and how it relates to other jobs in the organization. Therefore job design and redesigns objective is to connect the needs of the individuals performing various job with the productivity needs of the organization. This supports the assertion of Achieng et al. (2014) who posits that an important aim of job design and redesign is to provide individuals with meaningful work that fits effectively into the flow of the organization. The goal of job design is simplifying, enriching, enlarging, or otherwise changing jobs to make the efforts of each employee fit together better with jobs performed by other employees. Similarly, Davis (2005) holds that job design and redesign is more likely to improve performance when the changes in job contents are sufficiently non-trivial to be perceptible to the workers, typically in terms of greater self-regulation, diversity, meaningfulness, challenge, and social responsibility; and when the changes in job contents are part of a more pervasive programme of improved working policies and practices, which include elements of adequate pay and job security, proper resources and working conditions, increased mutual influence by people at all levels, and constructive labour management relations.

\section{Elements of Job Design}

Job design has to be considered within the context of organization design, but it must also take into account the following elements.

(i) Job content: the actual content of the job should be designed to enable people to find their work meaningful. In addition, people need to have a sense of responsibility, and be able to see the link between the works they do and the end results of their work. Where possible, job content needs to allow people to use their 

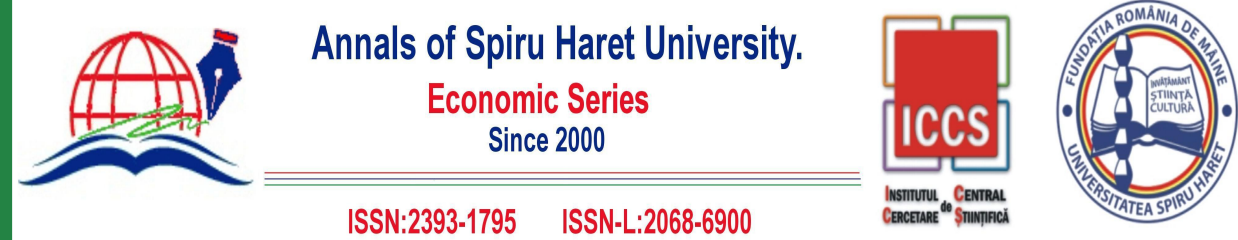

\section{Issue 3/2019}

current skills and develop new ones; see how their work contributes to a 'whole piece' of work; feel that the work they do matters and makes a difference, have a sense of autonomy; and receive regular and constructive feedback.

(2) Job Context: this includes factors such as ergonomic job design, work setting, technology, and flexible working options. When designing jobs, these contextual features all need to be taken into account; we know that a sense of autonomy arises in part when employees feel they have some choice and control over the context within which they work. Equally, in order to experience the 'safety' that Kahn (1990) notes to be so vital for engagement, employees need to feel their job is environmentally and ergonomically healthy.

(3) Work Relationships: studies have shown, and common sense tells us, that people are more likely to be engaged when they are in open, trusting and harmonious work settings. Jobs in the modern economy are more likely to be inter-dependent, and so, job design needs to consider not just only the job itself, but also the way the job holder is intended to interact with those around them [Kahn, 1990].

(4) Line Manager: the line manager has a vital role to play in bringing the individual's job design to life. Simply having a well-designed job will count for nothing with an unsupportive line manager who provides the feedback.

Taken together, these four elements need to be considered when determining how to design job optimally. The best solution will vary depending on context and job type. Therefore, from the foregoing it is crystal clear that job design is a combination of four basic considerations: (1) the organizational objectives the job was created to fulfil; (2) industrial engineering considerations, including ways to make the job technologically efficient; (3) ergonomic concerns, including worker's physical and mental capabilities; and (4) behavioural concerns that influence an employee's job satisfaction.

\section{Job Design Perspectives}

Job design or work design as it is identified by some scholars has a rich documented history dating back to the industrial revolution. Campion and Thayer (1987) identified four distinct job design models that draw from unique disciplines. This includes the mechanistic (i.e., scientific management and the industrial engineering approach focused on maximizing efficiency), motivational (i.e., the organizational psychology approach focused on maximizing job satisfaction and motivation), the biological model from ergonomics and medical sciences that focused 


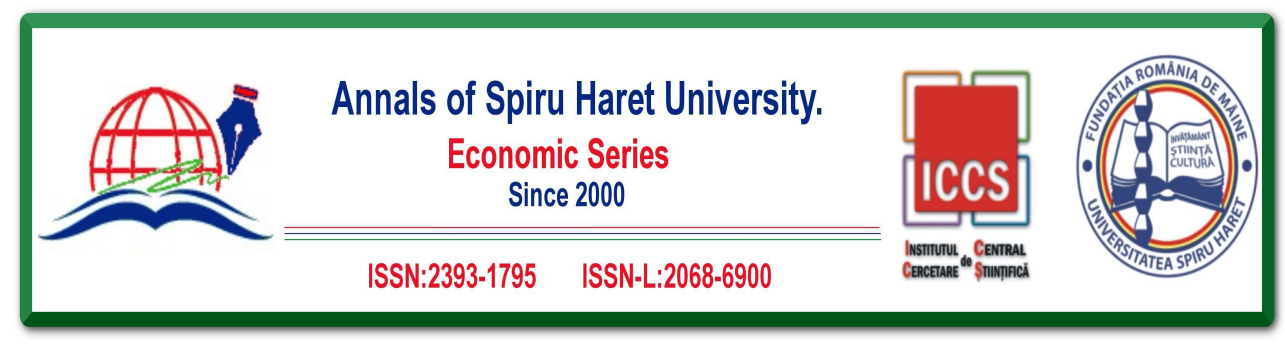

Issue 3/2019

on maximizing comfort and physical health, and the perceptual-motor model from experimental psychology and human factors that considers the attention and informational demands of the work. This interdisciplinary model highlights the discrete benefits and trade-off of each disciplinary-based approach, which can be particularly helpful when designing and redesigning job [Morgeson \& Campion, 2003].

The study of work is an important contribution of the scientific management movement. Industrial engineering, which evolves with this movement, is concerned with analyzing work methods and establishing time standards. Specifically, it involves the study of work cycles to determine which, if any, elements can be modified, combined, rearranged, or eliminated to reduce the time needed to complete the cycle. Industrial engineering constitutes a disciplined and objective approach to job design. Unfortunately, the concern of industrial engineering for improving efficiency and simplifying work methods may cause the behavioural considerations in job design to be neglected. What may be improvements in job design and efficiency from an engineering standpoint can sometimes prove psychologically unsound. For instance, the assembly line with its simplified and repetitive tasks embodies sound principles of industrial engineering, but these tasks are often not psychologically rewarding for those who must perform them. Thus, to be effective, job design must also provide for the satisfaction of behavioural needs [Bohlander \& Snell, 2007]. The impediment to the mechanistic approach is that employees are less satisfied and less motivated and this eventually translates into absenteeism, staff attrition, and health complaints and injuries related to physical wear, carelessness or repetition [Van de Ven \& Ferry, 1980].

However, in 1950s, the human relations advocate recognized the absence of attention to human needs in the mechanistic approach to job design and advocated for an approach that addressed work motivation and organizational behaviour. The motivational perspective to job design takes into consideration social or peopleinteraction aspects as well as task variety, feedback, and achievement [Campion \& Thayer, 1987]. Recognizing that employees have feelings, motives and needs, organizational psychology developed two main theoretical approaches to motivational designs; the socio-technical and job characteristics theories. Socio-technical theory is concerned with the interdependence of both the social and technical systems of organizations. Its assumption is that the incremental gains of doing more of what is already being done and doing it better are restricted [Tonges, 1998]. The heart of the theory lies in the suggestion that in job designs, there should be a fit between design features of the organization and as of equal significance, a fit between the organization 


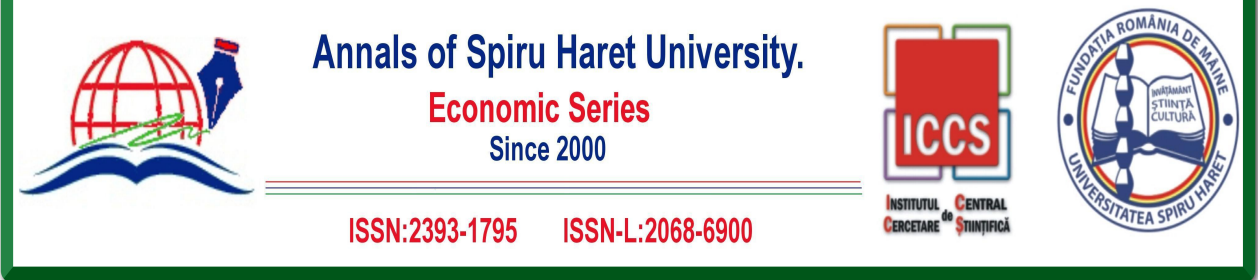

\section{Issue 3/2019}

and its environment [Lawler, 1996]. The socio-technical theory basically presented a shift in how work and organizations are to be designed [Trist, 1981]. In the outline of the theory, self-managed teams are actually the core building blocks of organization designs [Trist, 1981; Macy \& Izumi, 1993; Lawler, 1996; Siruri \& Muathe, 2004; Parker et al., 2017]. Job design needs to include both how the work is designed and how the workers are organized. Socio-technical theory has, in particular, encouraged the innovation of autonomous work groups [Holman et al., 2002].

The second main theoretical approach is job characteristics and this has been strongly influenced by the work of Hackman and Oldham (1975) and the job characteristics model. They advocated that well-designed jobs lead to high motivation, high-quality performance, high satisfaction, and low absenteeism and staff turnover. These outcomes occur when employees experience three critical psychological states (noted in the middle column of the figure below):

i. They believe they are doing something meaningful because their work is important to other people.

ii. They feel personally responsible for how the work turns out.

iii. They learn how well they perform their jobs.

Addition, they proposed that five core job dimensions are instrumental in producing these psychological states. The five core job dimensions include task variety, task identity, task significance, autonomy, and feedback. Task variety is related to the fact that completing repetitive tasks offers no challenges to employees and can cause them to lose interest and become dissatisfied. Task identity suggests that employees are more satisfied when they have an opportunity to complete a whole and identifiable piece of work. Task significance suggests that workers need to feel responsible for their work and understand the importance of their work and how it positively impacts on the lives of others. Autonomy is the individual's independence and discretion in making decisions. Finally, feedback suggests that everyone needs information about their job performance. These five core job dimensions affect the outcome of work by influencing three psychological states (experienced meaningfulness, responsibility, and knowledge of actual results). Once these three psychological states are activated, supposedly work motivation, job satisfaction and job performance should improve. It is further suggested that these outcomes would be more important for workers with high growth needs. 


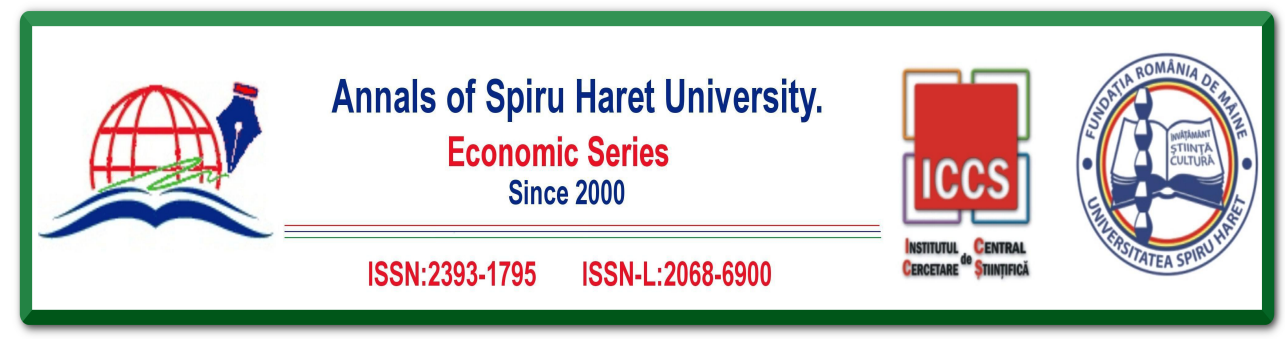

Issue 3/2019

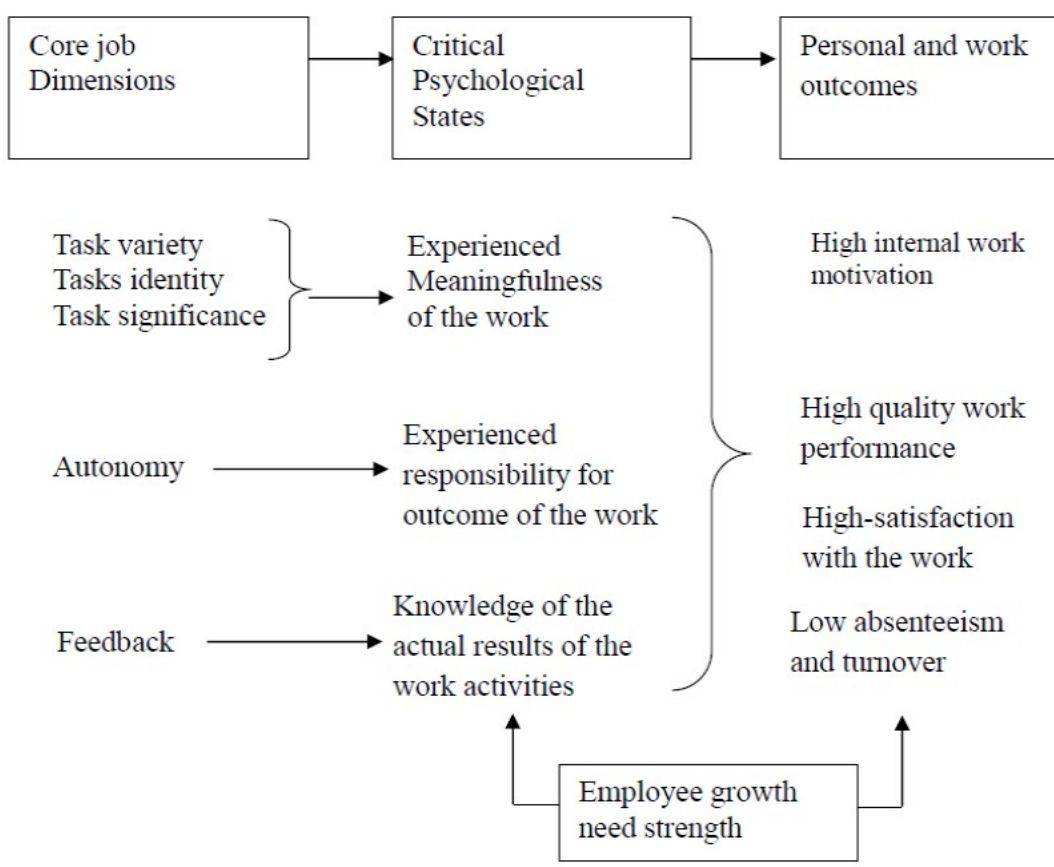

Fig. 1. Task Characteristics and Work Motivation

Source: A New Strategy for Job Enrichment by Hackman and Oldham (1976)

The goal of this model is to design job so that it will be personally satisfying and intrinsically rewarding. This model along with the job design survey has guided a significant number of job design studies [Hackman \& Oldham, 1980]. The job characteristics model appears to work best when certain conditions are met. One of these conditions is that employees must have the psychological desire for the autonomy, variety, responsibility, and challenge of enriched jobs. When this personal characteristic is absent, employees may resist the job design and redesign effort. In addition, job design or redesign efforts almost always fail when workers lack the physical or mental skills, abilities, or education needed to perform the job. Forcing enriched jobs on individuals lacking these traits can result in frustrated employees [Bohlander \& Snell, 2007]. 


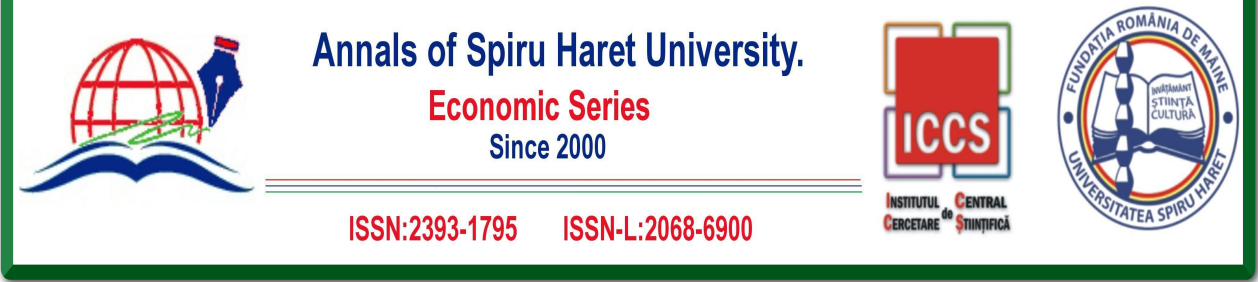

\section{Issue 3/2019}

In attempts to accommodate the human capabilities and limitations of those who are to perform a job, a biological perspective to job design was developed. The approach is concerned with adapting the entire job system - the work itself, the work environment, the machine and equipment, and the processes to match human characteristics. In short, it seeks to fit the job to the person rather than the person to the job. Its main premise was to minimize the harmful effects of carelessness, negligence, and other human fallibilities that otherwise may cause product defects, damage to equipment, or even the injury or death of employees [Bohlander \& Snell, 2007]. The advantages of jobs exhibiting a biological approach include less physical fatigue, fewer health complaints, fewer inquires, lower absenteeism and possibly increased job satisfaction because they are physical less strenuous [Avhieng et al., 2014]. The biologic approach improves productivity and morale and yields positive return on investment. It is a broad approach to improving human performance. Unfortunately, more workplace inquires occur yearly resulting from motions such as lifting, bending, and typing.

Two additional contemporary perspectives deserve mention. They are relational approach and learning and development approach to job design. Grant (2007) developed the idea of 'relational job design', which focuses on "the relational architecture of jobs that increases the motivation to make prosaically difference by connecting employees to the impact they are having on the beneficiaries of the work. Empirical research has supported and extended this conceptual model [e.g., Grant, 2008; Grant \& Parker, 2009; Johns, 2010; Parket et al., 2013; Parker et al., 2017]. This important research clearly recognizes that job exists in a social context that can have a fundamental affect on employees. Also, Parker (2014) has advanced a learning and development approach to job design. This approach draws from a diverse body of research showing that jobs with certain characteristics, such as high demands and control [Karasek \& Theorell, 1990], autonomy and complex work with low supervision [Kohn \& Schooler, 1982], can promote employee's learning and development. The learning and development perspective recognizes that job design promotes morale, cognitive, and personality development. Li et al. (2014) showed that job demands and control predict the development of a more proactive personality, which in turn has lagged beneficial effects on job characteristics. The focus on learning and development as a result of job design dovetails with advances in the careers' field [Parker et al., 2017]. Likewise, coming from a career perspective, Hall and Heras (2010) advocated "the need to design smart jobs that contribute to and self-identify of the employee". 


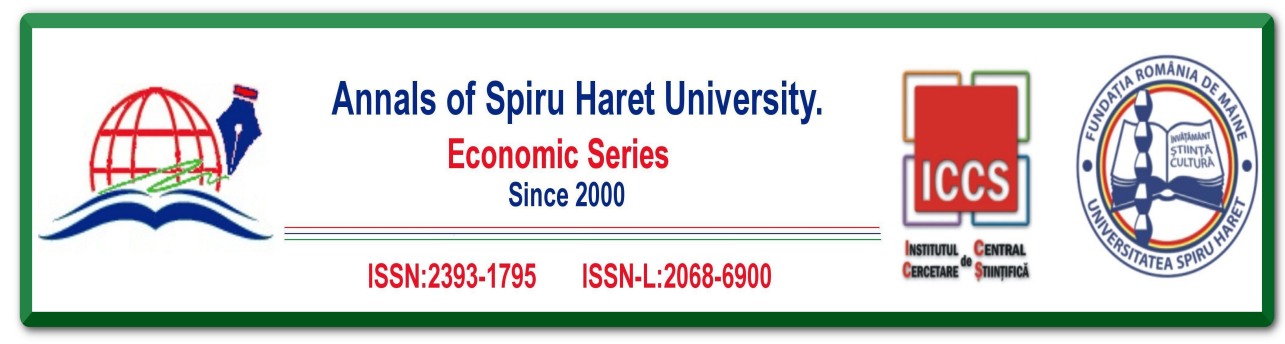

Issue 3/2019

Commenting on the importance of job design in contemporary management literature, Parker et al. (2017) affirm that the topic of job design is thus often central to business and organizational discussion, and yet is not clearly referred to using the language more commonly used by academics. Job design is perhaps so ubiquitous in its breadth of application that the impact of the topic is somewhat unnoticed. Our analysis shows that references to scientific management peaked around 1918 and then decline, whereas core job design terms such as work design, job characteristics, job demands/control, socio-technical, role conflict and other role demands all peaked in the early 1980 s with a decline thereafter. However, in contrast to these traditional terms, there is a dramatic increase in the use of terms associated with teamwork as well as clear increase in the use of newer terms such as empowerment, demands, time pressure, emotional demands, cognitive demands, and electronic monitoring, thus showing the continued contemporary relevance of job design issues. Therefore, job design is important in contemporary business management for developing talent through job rotation, boosting innovation, and enabling outcomes like virtuality and sustainability.

\section{Approaches to Job Design}

Especially in organizations that depend on highly motivated knowledge employees, keeping talented employees may require letting them design their own jobs so that their work is more interesting than it would be elsewhere. Some approaches to construct an effective job design to increase intrinsic rewards and therefore motivation are job rotation, job enlargement and job enrichment, which can be used to engage, encourage and involve employees in their work.

\section{Job Rotation}

This is "the movement of employees from one task to another to reduce monotony by increasing variety" [Armstrong, 2009]. Similarly, Dessler and Varkkey (2009) defined job rotation as a systematic shifting of employees from one job to another and, in most cases, over prearranged intervals. It essentially involves rotating employees from one routine task to another to alleviate boredom. An essential aspect of job rotation is in its innate ability to promote organizational learning. Ortega (2001) argues that job rotation can promote organization learning better than work specialization in circumstances where there is little information about the relative importance of different job tasks. With the benefits that accrue from organizational 

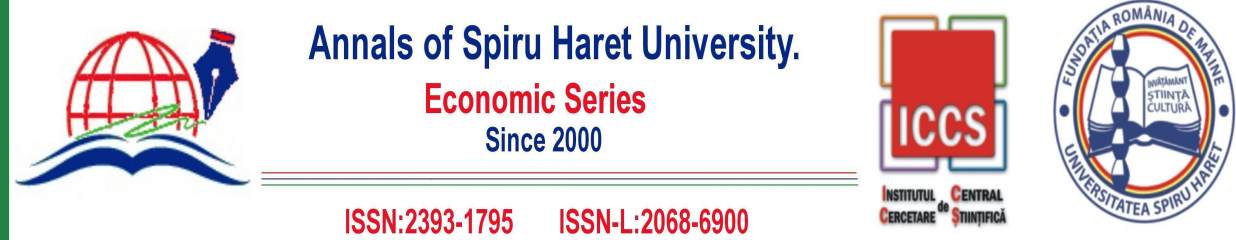

\section{Issue 3/2019}

learning, it means that job rotation is an inevitable aspect of job design. However, Cosgel and Miceli (1999) argued that job rotation should only be applied when the incremental benefits of its application outweigh the benefits of work specialization. This means that it is absolutely essential to carry out a cost benefit analysis before using this kind of job design and it should only be applied where it is rational to do so.

\section{Job Enlargement}

This is the process of giving employees additional tasks at the same time to mitigate boredom [Bateman \& Snell, 2011]. Similarly, Dessler (2005) views job enlargement as an activity that entails assigning employees' additional same level activities, thus increasing the number of activities they perform. This means that job enlargement increases the scope of work laterally without necessarily increasing job tasks in a horizontal manner [Siruri \& Muathe, 2014]. The significance of job enlargement lies basically in the role it plays in fulfilling lower needs of Abraham Maslow's hierarchy of needs theory, thus is an essential determinant of job satisfaction [Chyng \& Ross, 1977]. This argument, however, indicates that job enlargement plays a critical role in meeting an employee's basic and psychological needs in Maslow's continuum of the needs hierarchy given such an employee the vigour to enjoy his/her work and thus enhance workplace productivity. However, job enlargement has historically been criticized as decreasing social interactions and increasing workload, thereby decreasing job satisfaction and commitment of employees [Donaldson, 1975]. Essentially, this arises from the fact that job enlargement increases the volume of work, thereby reducing the socializing time, ultimately leading to lowered job satisfaction and employee commitment.

\section{Job Enrichment}

This is a process of changing a task to make it inherently more rewarding, motivating, and satisfying [Bateman \& Snell, 2011]. Basically, job enrichment entails giving employee's greater autonomy and control thereby influencing employee's affective and motivational systems by chiefly providing multiple paths to job goals [Griffin et al., 2001]. Originally popularized by Frederick Herzberg, job enrichment is touted as fulfilling the high motivational needs of employees, such as selffulfilment and self-esteem, while achieving long-term job satisfaction and performance goals. He further discusses five factors for enriching jobs and thereby 76 


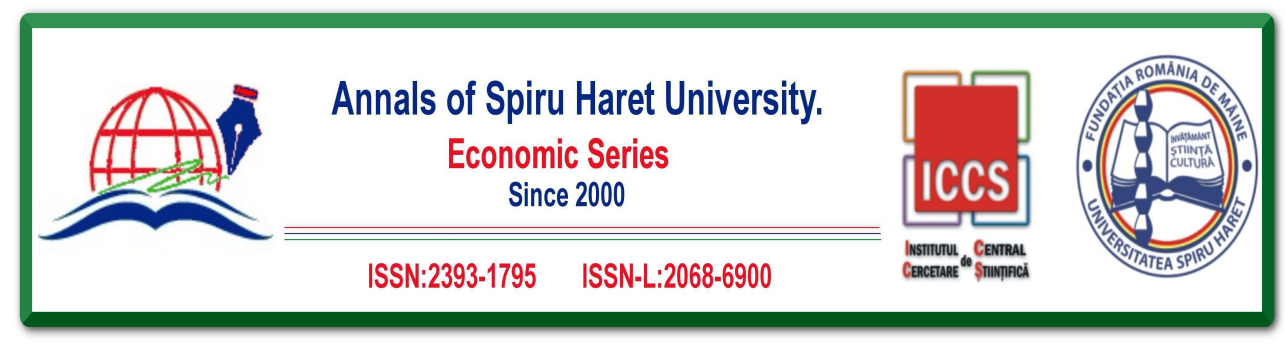

Issue 3/2019

motivating employees: achievement, recognition, growth, responsibility, and performance of the whole job versus only parts of the job [Herzberg, 1968]. These factors allow employees to assume a greater role in the decision-making process and become more involved in planning, organizing directing, and controlling their own work. Where jobs have been enriched, employee satisfaction tends to increase with a decrease in labour turnover and absenteeism [Saavedra \& Kwun, 2000]. However, in spite of the benefits to be achieved through job enrichment, it must not be considered a panacea for overcoming production problems and employee discontent. Kelly (2982), Pollert (1991) and Bohlander and Snell (2007) argue that job enrichment can lead to demotivated employees as a result of employees disliking job enrichment as a form of workplace intervention. In the same vein, other scholars argues that enrichment techniques like total quality management, self-management teams and quality cycles encourage peer surveillance which can lead to lower job satisfaction [Delbridge et al., 1992; Garrahan \& Stewart, 1992; Sewell \& Wilkinson, 1992; Siruri $\&$ Muathe, 2014]. This argument implies that it is fundamental to understand what motivates employees before undertaking job enrichment since without such knowledge job enrichment interventions can be counterproductive.

\section{Employee Performance}

The issue of performance in organization is broad and has been subject of discourse among social scientists from a wide range of disciplines as it is being used synonymously with productivity, efficiency, effectiveness and more recently competitiveness [Cooke, 2000]. Azreen (2011) affirms that performance is a function of capacity (ability, health, intelligence, etc.), willingness (motivation, job satisfaction, status, etc.), and opportunity to perform (tools, equipment, working conditions, coworkers and leader behaviour, etc.). Essentially, performance is related to the extent to which an employee or organization is able to accomplish assigned tasks and how the accomplished tasks contribute to the realization of the organizational goals [Okolie \& Omole, 2017].

The term employee performance is interchangeably used as job performance, employee productivity, and employee efficiency and employee effectiveness. Gitman and McDaniel (2005) defined employee performance as employee's contribution to the organization, arising from the job objectives, schedules, deadlines, product/ service requirements. Employee performance can also be seen as behaviour exhibited or something done by employee. Daft (2008) sees employee performance as 


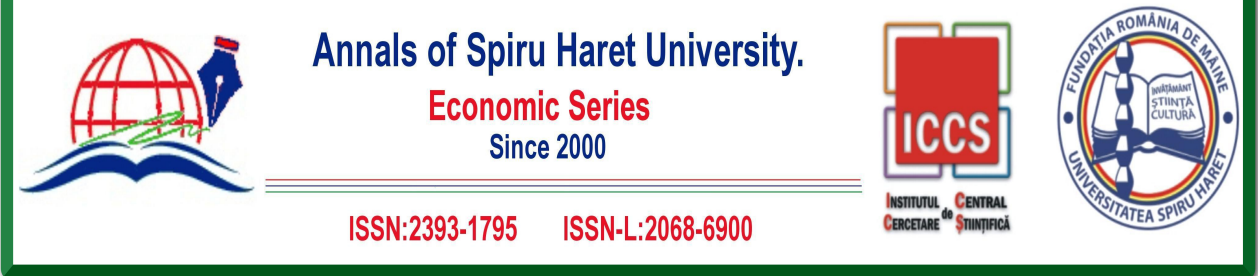

\section{Issue 3/2019}

employee output of goods/services divided by the employee input. According to Ikyanyon and Ucho (2014), employee performance refers to the behaviour individuals engage themselves in or produce that are in line and contribute to an organization's goal. Therefore, employee performance is more of actions rather than feelings derive from job and thus encompasses the efficiency and effectiveness that employee demonstrate in carrying out task in the workplace. Review of extant literature has shown that high performing organizations are more likely to survive and compete favourably in this ever changing and competitive business environment [Saari \& Judge, 2004]. They are more likely to have higher customer satisfaction and market share [Daft, 2008]. However, in achieving this, the organization needs not only highly motivated but also satisfied and psychologically balanced employees to increase performance and productivity in the organization.

Therefore, organizations that create work environments that attract, motivate and retain hardworking employees will be better positioned to succeed in a competitive national and international business environment that demands quality and costefficiency because the success of any business depends on employees' performance. One of the most effective ways to increase business performance and profit is to increase the performance of employees, from the lowest levels of the organization to senior management [Ivancevich, 1998]. In addition, Al-Ahmadi (2009) adds that performance improvement is not only a result of well functioning system but also depends on effective human resource strategies that succeed in recruiting and maintaining a committed and motivated workforce.

\section{Job Design and Employee Performance}

The various psychological works on employee motivation contain many claims that changes in job design can be expected to produce better employee job performance and job satisfaction [Lawler, 1969]. Also, attention has been drawn to the theory that the redesign of work or job as a strategy for organizational change is expected to enhance employee's motivation and performance [Onimole, 2015]. However, modern behavioural scientists like Argris, Maslow, McGregor, Likert, Herzberg, Hackman and Oldham, Cummings and Worley, Morgeson and Campion, Trist and Bamforth, Griffin, Bohlander \& Snell believe that work should be challenging, complex, varied and meaningful so that the higher order needs of employees are satisfied. In the view of Garg and Rastogi (2006), well designed jobs can have a positive impact on both employee satisfaction and quality of performance. 


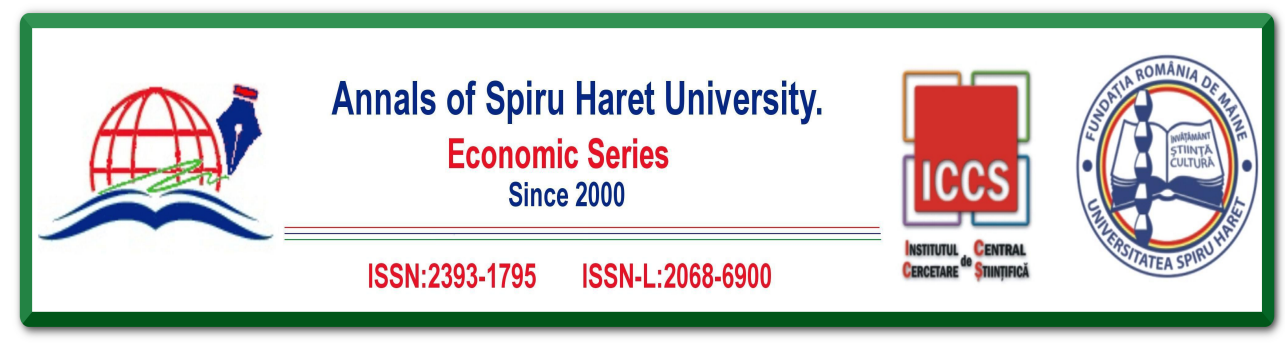

Issue 3/2019

The perceived work demands, job control and social support through job design leads to high productivity [Love \& Edwards, 2005 as cited in Garg \& Rastogi, 2006]. Similarly, Campion, Mumford, Morgeson and Nahrgang (2005) posit that status of work or job has a substantial impact on an employee's performance and attitude. Hence, there is a strong relationship between job design and employee performance. Outcomes of an effectively designed job according to the desires or psychological perception of the employee are involvement and satisfaction which ultimately lead to performance maximization and goals achievement [Kahn, 1992]. Three approaches can be used to achieve an employee's motivation and satisfaction. These include job rotation, job enlargement and job enrichment.

\section{Job Rotation and Employee Performance}

Job rotation gives the employees the opportunity to develop skills in a variety of changing jobs. In job rotation, employees are given the opportunity to make lateral moves majority of the time, but job rotation can also involve a promotion. Essentially, job rotation is a method used for employee development. This means that when properly designed and executed, job rotation can result in improvement of capacity of employees and hence resulting in enhanced task performance and productivity [Siruri \& Muathe, 2014]. According to Ostroff and Kozlowski (1992), job rotation facilitates information sharing and socialization and these result in a more knowledge employee base and the resultant effect is that employees undertake their tasks much better, hence enhancing workplace productivity for the employees individually and collectively. In addition, Zeira (1974) argued that job rotation is an important technique of augmenting employee's task commitment and job involvement and as such plays an important role in facilitating normal functioning of organizations, thereby helping to drive efficiency and effectiveness, which ultimately leads to enhanced workplace productivity. Therefore, job rotation gives employees a broad knowledge of the business that enhances their value to the organization and at the same time it opens up opportunities for their career development.

\section{Job Enlargement and Employee Performance}

Job enlargement generally involves only the horizontal extension of the job, that is, more of the same thing merely makes a job structurally bigger [Cole, 2002]. Pierce (1980) argued that job enlargement is a variant of the motivational perspective of designing jobs. The implication of this is that it is very difficult to view a job 


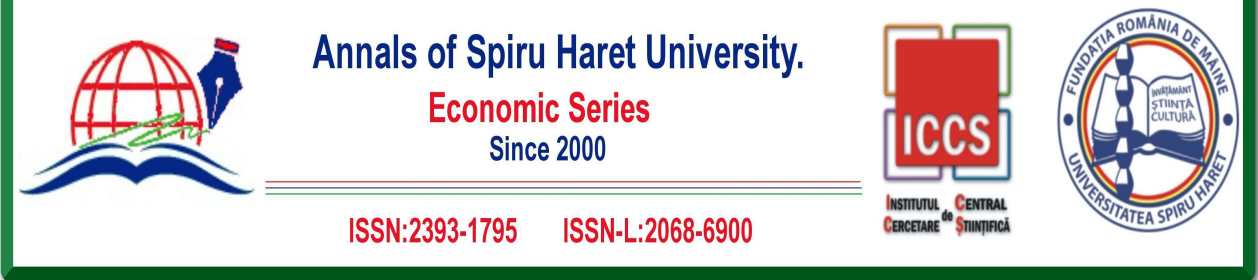

\section{Issue 3/2019}

enlargement intervention as independent of an employee's motivation. That is, if such interventions are not employee centric, then they would defeat the very purpose of their execution, as low employee motivation would serve to defeat the benefits of such job enlargement interventions. According to Bateman and Snell (2011), job enlargement leads to higher job satisfaction, better error detection and improved customer service. Achieng et al. (2014) affirms that job enlargement is primarily concerned in improving employee performance. However, Lowe (2003) argued that job enlargement can serve to increase role uncertainty and hence lead to role conflict. This thus calls for a careful implementation of job enlargement interventions for, if not carefully done, the resultant effects can be disaster.

\section{Job Enrichment and Employee Performance}

One of the ways of tackling the issue of employee performance and satisfaction is to enhance the motivating factors in job [Cole, 2002]. The term 'job enrichment' was coined by Herzberg (1968) to denote the vertical enlargement of a job by adding responsibility and opportunity for personal growth. Essentially, job enrichment is requisite to enhancing employees' efficiencies, innovations, capability, reasoning faculty, and competence [Lynton \& Paareek, 2000] which will improve organizational performance [Davoudi, 2013] and as well help in gaining competitive edge [Armstrong, 2010]. In addition, Cherati, Mahdavi and Rezaeian (2013) posits that the level of job enrichment goes a long way in determining how effective and committed an employee will contribute to organizational goals and objectives. Therefore, organizations who seeks for greater performance and distinctive advantage must give better chances for employees' freedom, autonomy, control, skill varieties, and responsibility [Davoudi, 2013] which constantly helps to reduce rigidity, managerial monotony, lack of creativity and employees' dissatisfaction [Salau et al., 2014]. Employees' autonomy and control has often been as a strategic driving force to facilitate peaceful co-existence, affection, recognition, friendliness, freedom, etc., that are crucial for efficient performance capable of enhancing organizational effectiveness [Lawal, 2005]. Al-Nsour (2012) examined the inevitable role of job enrichment played on employee and organizational performance. Part of the roles are internal work motivation, greater commitment, employees retention, job satisfaction, distinctive and competitive advantage, improving workplace opportunities which have significant and important effects on corporate success. 


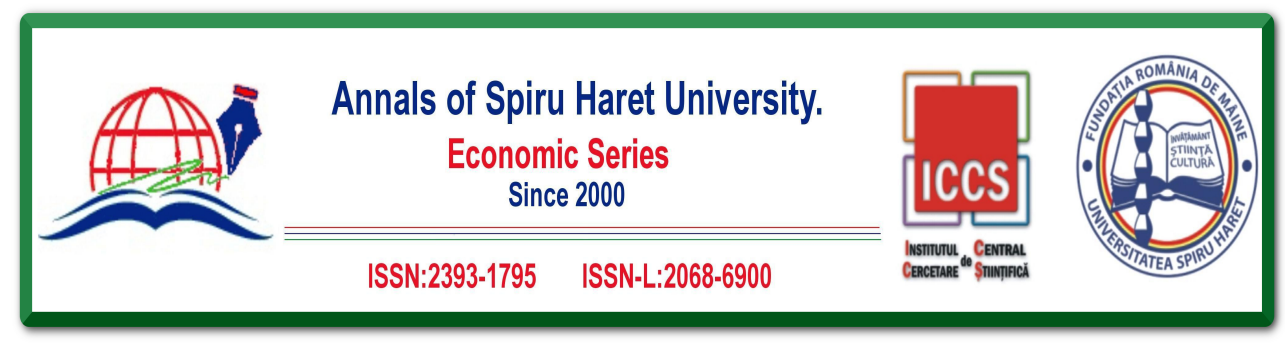

Issue 3/2019

\section{Theoretical Framework}

Studies on job design have largely been based on Herzberg's Factor Theory and Hackman and Oldham's job characteristics model. However, given that the study seeks to take organization as system characterized by interdependencies of variable, the study will be anchored on the tenets of the Expectancy Theory. In a nutshell, expectancy theory states that if an employee can see links between his/her efforts and performance, and between performance and rewards, and if those rewards are personally valuable to him or her then he or she will be motivated to put in the required effort [Cole, 2002]. The relevance of this theory to job design is considered by Lawler (1969) as follows: “...if changes in job design are going to affect an individual's motivation they must either change the value of the outcomes that are seen to depend on effort, or positively affect the individual's belief about the probability that certain outcomes are dependent upon effort. The argument is that job design changes can have a positive effect on motivation because they can change an individual's beliefs about the probability that certain rewards will result from putting forth high level of effort".

Lawler, in fact, uses Maslow's list of needs to illustrate the application of theory to job design. He considers extrinsic rewards as mostly satisfying lower level needs, while intrinsic rewards seem to satisfy higher level needs. The key rewards, or motivators, according to Lawler, are the intrinsic rewards; since they are derive from the job itself. In terms of job design factors, Lawler favours the follow:

i. The job should allow for meaningful feedback.

ii. The job should test the individual's value abilities.

iii. The job should permit a great amount of self-control.

These ideas have been taken a stage further by Hackman (1977), who suggests that meaningfulness, responsibility, and knowledge of results do contribute to increased motivation and performance at work.

\section{Research Hypotheses}

The following null hypotheses were formulated to guide the researchers in finding answers to the research questions:

i. $\mathrm{H}_{1}$ : There is no significant relationship between job rotation and employee performance in Nigerian Bottling Company Plc, Benin City.

ii. $\mathrm{H}_{2}$ : There is no significant relationship between job enlargement and employee performance in Nigerian Bottling Company Plc, Benin City. 


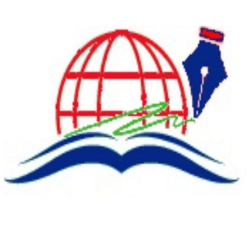

Annals of Spiru Haret University.

Economic Series

Since 2000
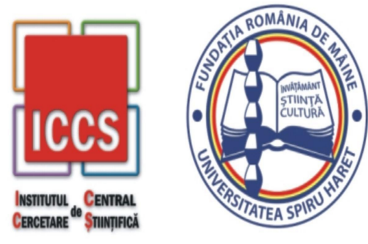

Issue 3/2019

iii. $\mathrm{H}_{3}$ : There is no significant relationship job enrichment and employee performance in Nigerian Bottling Company Plc, Benin City.

\section{Conceptual Model}

This study focused on the relationship between job design (job rotation, job enlargement and job enrichment) and employee performance in Nigerian Bottling Company Plc, Benin City. After the review of extant literature, we have analysed that job design has a strong effect on the performance of the employee. However, as obtained in the literature reviewed above, we proposed the following model depicted in fig. 2. The model shows that job rotation, job enlargement and job enrichment are independent variables, while employee performance is the dependent variable.

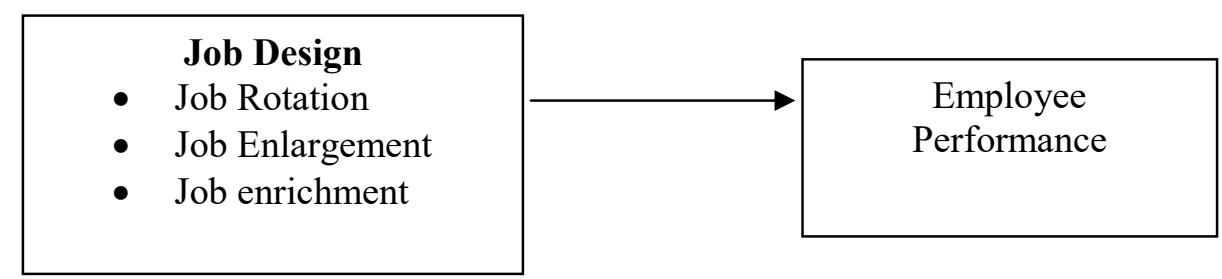

Fig. 2. Conceptual Framework of the Study

Source: Author's construction

\section{Methodology}

This study examined the relationship between job design and employee performance in Nigerian Bottling Company Plc, Benin City. The descriptive research approach was adopted. Research survey method through the use of structured questionnaire designed to elicit needed information from the respondents was adopted. The survey sample size was 309 and out of which 237 questionnaire were duly filled and returned representing $76.7 \%$ response rate. The responses obtained were subjected to analysis with the use of Statistical Package for Social Science (SPSS) and adoption of Pearson correlation and Regression Analysis method.

\section{Data Analysis and Discussion of Findings}

Table 1 below shows the nature of the relationship that existed between job design practices (job rotation, job enlargement and job enrichment) and employee performance. 


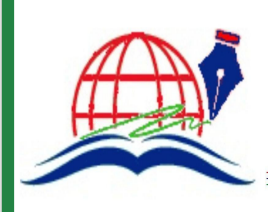

Annals of Spiru Haret University.

Economic Series

Since 2000

ISSN:2393-1795 ISSN-L:2068-6900
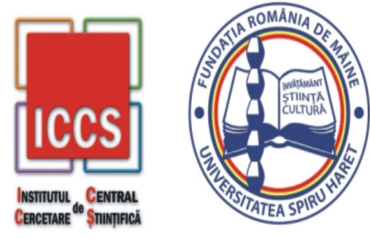

Issue 3/2019

Table 1. Correlation Coefficient Matrix

\begin{tabular}{|c|c|c|c|c|c|}
\hline Variables & & Job rotation & $\begin{array}{c}\text { Job } \\
\text { Enlargement } \\
\end{array}$ & $\begin{array}{c}\text { Job } \\
\text { Enrichment } \\
\end{array}$ & $\begin{array}{c}\text { Employee } \\
\text { Performance }\end{array}$ \\
\hline Job rotation & $\begin{array}{l}\text { Pearson correlation } \\
\text { Sig. (2-tailed) } \\
\mathrm{N}\end{array}$ & $\begin{array}{l}1 \\
237 \\
\end{array}$ & & & \\
\hline $\begin{array}{l}\text { Job } \\
\text { enlargement }\end{array}$ & $\begin{array}{l}\text { Pearson correlation } \\
\text { Sig. (2-tailed) } \\
\text { N }\end{array}$ & $\begin{array}{l}0.232 * * \\
0.093 \\
237\end{array}$ & $\begin{array}{l}1 \\
237 \\
\end{array}$ & & \\
\hline $\begin{array}{l}\text { Job } \\
\text { enrichment }\end{array}$ & $\begin{array}{l}\text { Pearson correlation } \\
\text { Sig. (2-tailed) } \\
\text { N }\end{array}$ & $\begin{array}{l}0.217 * * \\
0.000 \\
237\end{array}$ & $\begin{array}{l}0.453 * * \\
0.004 \\
237 \\
\end{array}$ & $\begin{array}{l}1 \\
237 \\
\end{array}$ & \\
\hline $\begin{array}{l}\text { Employee } \\
\text { performance }\end{array}$ & $\begin{array}{l}\text { Pearson correlation } \\
\text { Sig. (2-tailed) } \\
\text { N }\end{array}$ & $\begin{array}{l}0.209 * * \\
0.000 \\
237\end{array}$ & $\begin{array}{l}0.602 \\
0.511 \\
237 \\
\end{array}$ & $\begin{array}{l}0.529 * * \\
0.000 \\
237\end{array}$ & $\begin{array}{l}1 \\
237\end{array}$ \\
\hline
\end{tabular}

** Correlation is significant at the 0.01 level (2-tailed). The above table clearly shows that there is a positive and significant relationship between job design practices and employee performance. The results in Table 1 revealed that job rotation $(r$-value $=0.209$ and $p$-value $=0.000)$, job enrichment $(r-$ value $=0.529$ and $\mathrm{p}$-value $=0.000)$ are significantly related to employee performance but the significance of its relationship with job enlargement $(\mathrm{r}$-value $=0.602$ and $\mathrm{p}$-value $=0.511)$ could not be established.

Table 2. Multiple Regression Analysis between Job Design and Employee Performance

\begin{tabular}{|l|l|l|l|}
\hline Dependent variable & Independent variables & Std. Beta ( $\beta)$ & Results \\
\hline Employee & Job Rotation & 0.041 & Rejected \\
performance & Job Enlargement & 0.023 & Rejected \\
& Job Enrichment & $0.587 * *$ & Accepted \\
\hline & $\mathrm{R}^{2} * 746$ & & \\
& Adjusted $\mathrm{R}^{2} * 406$ & & \\
& Sig. F $46.275^{* *}$ & & \\
\hline
\end{tabular}

Note: The level of significance: $* \mathrm{p}<0.05$

The multiple regression table (Table 2) above shows that job design significantly influences employee performance (Sig. F $=46.275, \mathrm{p}<0.05$ ). Further evidenced is the fact that the percentage of variance in employee performance explained by job design is $40.6 \%$, which showed the extent of the effect of job design on employee performance. Table 2 further shows that only job enrichment has strong impact on employee performance due to the beta value $(\beta)$ of 0.587 and a significant value of 


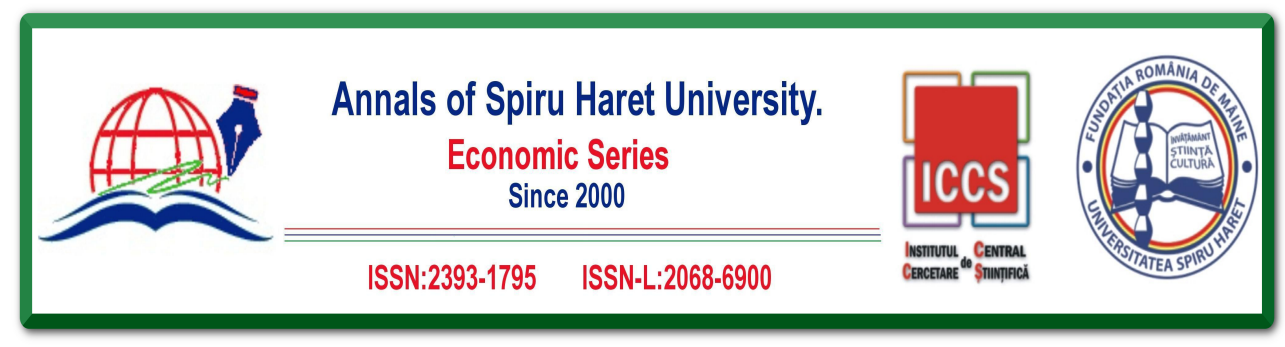

Issue 3/2019

0.000 , which is less than 0.05 . Therefore, hypotheses $\mathrm{H}_{1}$ and $\mathrm{H}_{2}$ are rejected and only $\mathrm{H}_{3}$ is accepted.

\section{Conclusion and Recommendations}

The objective of the study was achieved as it revealed that there are positive correlation between job rotation, job enlargement and job enrichment and employee performance. The findings have established that the relationship between job rotation together with job enlargement and employee performance is positive but very weak. In fact, there is no significant effect. So this clearly shows that only job enrichment has significant effect on employee performance in Nigeria Bottling Company Plc, Benin City. As the review of the literature revealed, research has established that job rotation should only be applied when the incremental benefits of its applications outweigh the benefits of work specialization [Cosgel \& Miceli, 1999]. This means that it is necessary to carry out a cost benefit analysis before this kind of job design and it should only be applied where it is rational to do so. Also, job enlargement has historically been criticized as decreasing social interactions and increasing workload, thereby decreasing job satisfaction and commitment of employees [Donaldson, 1975]. In essence, we propose job enrichment as a powerful vehicle for mitigating potential negative effects (and enhancing potential positive effects) of technological and social change, as well as for enabling these changes to be more effective. As a suggestion for a future study, the researchers can look at the factors that exist in job rotation and job enlargement that reduce the percentage of influence on employees' performance. Although according to previous researchers, job rotation and job enlargement can reduce stress and motivate employees [Ali, 2013], on the whole this is not a suitable practice in the production sector especially within the population of this study. Based on the findings of this study, it is recommended that:

i. Human resource manager of the Nigeria Bottling Company Plc, Benin City and HR managers of other organization alike should study the psychology of employees before designing jobs, task or assignment for them, because an effective job design should be according to the psychological perception of an employee - not all the employees can be motivated and satisfied by a specific job design.

ii. Employees should be interviewed at the time of recruitment in order to hire the desired employees whose psychology fits the existing job design. This is because, if the nature of jobs, tasks, and assignments matches with the psychology of employee, the employee tends to be more effective, productive, and helpful in achieving his/her personal goals and organization goals. 


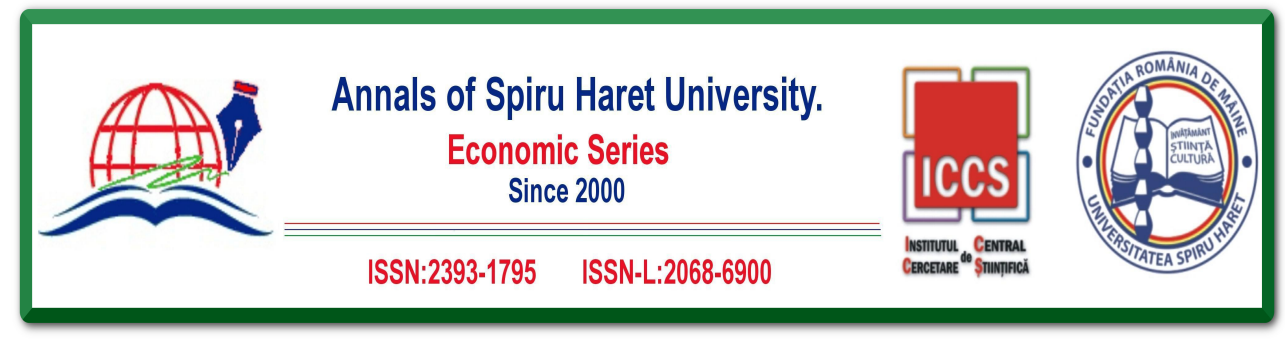

Issue 3/2019

iii. Employees should be involved in the process of designing their job characteristics that suits their psychological perceptions.

iv. Human resource managers should take account of individual differences, attributes and people orientation to work by reviewing and redesigning job at regular intervals. This is because an effective job design should be aligned to the employee's goals as well as organizational outcomes.

v. Existing job design of valued employees also should be analysed to provide them with better work arrangement to enhance their efficiency and retention within the organization.

\section{References}

[1] Achieng, O.E., Ochieng, I., \& Owuor, S. (2014). "Effect of job redesign on employee performance in commercial banks in Kisumu, Kenya." Greener Journal of Business and Management Studies, 4 (4), 115-137.

[2] Al- Nasour, M. (2012). "Relationship between incentives and organization performance for employees in the Jordanian Universities." International Journal of Business and Management, 7 (1), 78-89.

[3] Al-Ahmadi, H. (2009). "Factor affecting performance of hospital bankers in Riyadh Region, Saudi Arabia." International Journal of Health Care Quality Assurance, 22 (1), 40-54.

[4] Al-Badarin, R. Q., \& Al-Azzeam, A. H. (2017). "Job design and its impact on the job strain: Analysing the job as a moderating variable in the private hospitals in Irbid." International Journal of Humanities and Social Science, 7 (3), 152-168.

[5] Ali, N., \& Zia-ur-Rehman, M. (2014). "Impact of job design on employee performance, mediating role of job satisfaction: A study of FMCG's sector in Pakistan." International Journal of Business and Management, 9 (2), 70-79.

[6] Armstrong, M. Armstrong's Handbook of Human Resource Management Practice, $\left(11^{\text {th }}\right.$ Ed.). London: Kogan Page, 2009.

[7] Armstrong, M. A Handbook of Performance Management (4 ${ }^{\text {th }}$ Ed.). New Delhi: Kogan Page, 2010.

[8] Azreen, A. (2011). "The personality of team working." Journal of Personnel Management, 4 (3), 81-86.

[9] Bateman, T. S., \& Snell, A.S. Management. Leading \& Collaborating in a Competitive World, (9 ${ }^{\text {th }}$ Ed.) New York: McGraw-Hill, 2011.

[10] Bates, S. (2004). "Getting engaged." HR Magazine, 49 (2), 44-51.

[11] Bohlander, G., \& Snell, S. Managing Human Resources (14 ${ }^{\text {th }}$ Ed.). United States: Engage Learning, 2007. 


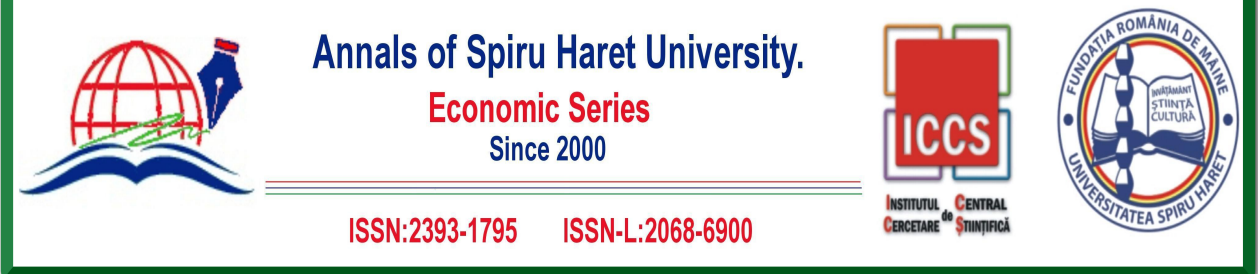

\section{Issue 3/2019}

[12] Campion, M.A., \& Thayer, P.W. (1987). "Job design: Approaches, outcomes, and trade-offs". Organizational Dynamics, 15 (3), 66-80.

[13] Campion, M.A., Mumford, T.V., Morgeson, F.P., \& Nahrgang, J.D. (2005). "Work redesign: Eight obstacles and Opportunities." Human Resource Management, 44(4), 367390.

[14] Cherati, H., Mahdavi, I., \& Rezaeian, J. (2013). "The mediating role of job satisfaction between spiritual intelligence and organizational commitment." International Journal of Research in Organizational Behaviour and Human Resource Management, 1 (1), 1-11.

[15] Chung, K.H., \& Ross, M.F. (1977). "Differences in motivational properties between job enlargement and job enrichment." Academy of Management Journal, 2 (1), 113-122.

[16] Cole, G.A. Personnel and Human Resource Management, ( $5^{\text {th }}$ Ed.). London: Engage Learning, 2002.

[17] Cooke, T. (2000). "Teamwork structures and worker perception: A cross national study in pharmaceuticals." International Journal of Human Resource Management, 16 (2), 276-279.

[18] Daft, L.R. New Era of Management. Ohio: Thompson South-Western, 2008.

[19] Davis, L.E. (2005). Developments in job design. In P.B. Warr (Ed.), Personal Goals and Work Design. London: Wiley.

[20] Davoudi, M., \& Mehdi, S. (2013). "Impact of job enrichment in organizational citizenship behaviour." SCMS Journal of Indian Management, 10 (2), 106-112.

[21] Delbridge, R., Turnbull, P., \& Wilkinson, B. (1992). "Pushing back the frontiers: Management control and work intensification under JIT/TQM regimes." New Technology, Work and Employment, 7, 97-106.

[22] Dessler, G., \& Varkkey, B. (2009). "Job rotation: costs, benefit and stylised facts." Journal of International and Theoretical Economics, 155, 301-320.

[23] Donaldson, L. (1975). "Job enlargement: A multidimensional process." Human Relations, 28 (7), 593-610.

[24] Garrahan, P., \& Stewart, P. The Nissan Enigma: Flexibility at Work in a Local Economy. London: Mansett, 1992.

[25] Gitman, L. J., \& McDaniel, C. The Future of Business. Ohio: Thompson South-Western, 2005.

[26] Grag, P., \& Rastogi, R. (2006). "A new model for job design: Motivating employee's performance." Journal of Management Development, 25 (6), 572-587.

[27] Grant, A.M. (2007). "Relational job design and motivation." Academy of Management Review, 32 (2), 393-417.

[28] Grant, A.M. (2008). "The significance of task significance: Job performance effects, relational mechanisms, and boundary conditions." Journal of Applied Psychology, 93, 108-124. 


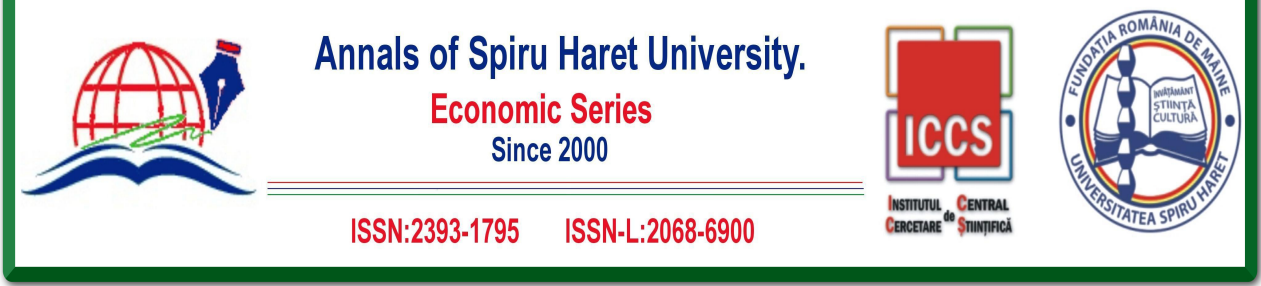

Issue 3/2019

[29] Grant, M.A., \& Parket, S.K. (2009). "Redesigning work design theories: rise of relational and proactive perspectives." The Academy of Management Annals, 3, 317-375.

[30] Griffin, M.A., Patterson, M.G., \& West, M.A. (2001). "Job satisfaction and teamwork: The role of supervisor support." Journal of Organizational Behaviour, 22, 537-550.

[31] Hackman, J.R., \& Oldham, G.R. Work Redesign. Menlo Park: Addison-Wesley Publishing, 1980.

[32] Hall, D. T.T., \& Heras, M.L. (2010). "Reintegrating job design and career theory: Creating not just good jobs but smart jobs." Journal of Organizational Behaviour, 31, 448-462.

[33] Hepworth, A. The Humanization of Staurt. London: Tiperley L. Business School, 2002.

[34] Herzberg, F. Work and Nature of Man. Cleveland: World Publishing, 1966.

[35] Herzberg, F. (1968). "One more time: How do you motivate employees." Business Review, New York.

[36] Holman, D., Clegg, C., \& Waterson, P. (2002). "Navigating the territory of job design." Applied Ergonomics, 33.197-205.

[37] Ivancevich, J.M. Job Analysis and Job Design, Human Resource Management (7 $^{\text {th }}$ Ed.). Irwin: McGraw-Hill, 1998.

[38] Jogns, G. (2010). "The essential impact of context on organizational behaviour." The Academy of Management Review 31, 386-408.

[39] Kackman, J.R., \& Oldham, G.R. (1976). "Motivation through the design of work: Test of a theory." Organizational Behaviour and Human Performance, 16, 250-279.

[40] Kahn, W.A. (1992). "To be fully there: Psychological presence at work." Human Relations, 45, 321-349.

[41] Kahn, W.A. (1990). "Psychological conditions of personal engagement and disengagement at work." Academy of Management Journal, 33, 692-724.

[42] Kelly, J.E. Scientific Management, Job Redesign and Work Performance. London: Academic Press, 1982.

[43] Kohn, M.L., \& Schooler, C. (1982). "Job conditions and personality: A longitudinal assessment of their reciprocal effects." American Journal of Sociology, 87, 1257-1286.

[44] Lawal, A.A. (2005). "Developing employees for improved performance." Journal of Liberal Studies, 1 (2), 71080.

[45] Lawler, E.E. (1969). "Job design and employee motivation." Personnel Psychology, $22,71-83$

[46] Lawler, E.E. From the Ground Up. San Francisco: Jossey-Bass, 1996.

[47] Lowe, G.S. Healthy Workplaces and Productivity: A Discussion Paper. Ottawa: Minister of Public Works and Government Services Canada, 2003.

[48] Lynton, S., \& Pareek, A. The Human Development Handbook. London: Kogan Page, 2000. 


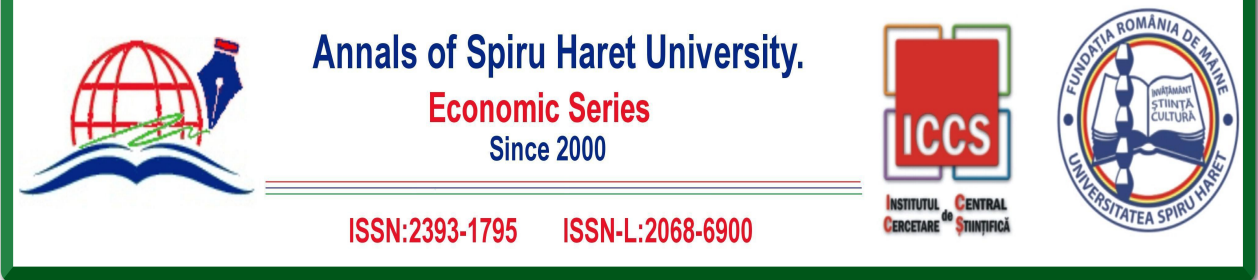

\section{Issue 3/2019}

[49] Magaji, N. Job Enrichment and Work Related Attitudes of Non-Academic Staff in Selected Private University in South-West Nigeria. Unpublished PhD Thesis of Babcock University, 2014.

[50] Morgeson, F.P., \& Campion, M.A. Work Design Handbook of Psychology: Industrial and Organizational Psychology. Hoboken: Wiley, 2003.

[51] Nanle, M. (2015). "Effect of job enrichment on employee motivation in selected private universities in South-West Nigeria." Journal of Arts, Science \& Commerce, 6(4), 67-77.

[52] Okolie, U.C., \& Omole, O.G. (2017). "Impact of teamwork on employees' job satisfaction and performance among polytechnic teachers: A case of Auchi Polytechnic, Auchi, Edo State." Human Resource Management Journal, 9 (1), 56-72.

[53] Onimole, S.O. (2015). "Work design and job satisfaction." International Journal of Humanities and Social Science, 5 (10), 202-207.

[54] Opath, H.D.N.P. Performance Evaluation of Human Resource ( $\left(1^{\text {st }}\right.$ Ed.) Colombo: The Author Publication, 2002.

[55] Ortega, J. (2001). "Job rotation as a learning mechanism." Management Science, 47 (10), 1361-1370.

[56] Ostroff, C., \& Kozlowski, S. (1992). "Organizational socialization as a learning process: The role of information acquisition." Personnel Psychology, 45, 849-874.

[57] Parker, S.K. (1998). "Enhancing role breadth self-efficacy: The roles of job enrichment and other organizational interventions." Journal of Applied Psychology, 83, 835-852.

[58] Parker, S.K. (2014). "Beyond motivation: Job and work design for development, health, ambidexterity and more." Annual Review of Psychology, 65, 661-691.

[59] Parker, S.K., Morgeson, F.P., \& Johns, G. (2017). "One hundred years of work design research: Looking back and looking forward." Journal of Applied Psychology, 102 (3), 403-420.

[60] Pierce, J.L. (1980). "Job design in perspective." The Personnel Administrator, 25, 67-74.

[61] Pollert, A. The Orthodoxy of Flexibility: Oxford: basil Blackwell, 1991.

[62] Saavedra, O., \& Kwun, S.K. (2000). "Affective states in job characteristics theory." Journal of Organizational Behaviour, 21, 131-146.

[63] Salau, O., Adeniji, A., \& Oyewunmi, A. (2014). "Relationship between elements of job enrichment and organizational performance among the non academic staff in Nigerian public universities. ” Management \& Marking, 12 (2), 173-189.

[64] Sarri, L. \& Judge, T. (2004). "Employee attitudes and job satisfaction." Human Resource Management, 43 (4), 395-407.

[65] Sewell, G., \& Wilkinson, B. (1992). "Someone to watch over me: Surveillance, discipline and just-in-time labour process." Sociology, 26 (2), 271-289.

[66] Siruri, M.M., \& Muathe, S.M.A. (2014). "A critical review of literature on job designs in socio technical systems." Global Journal of Commerce \& Management Perspective, $3(6), 44-49$. 


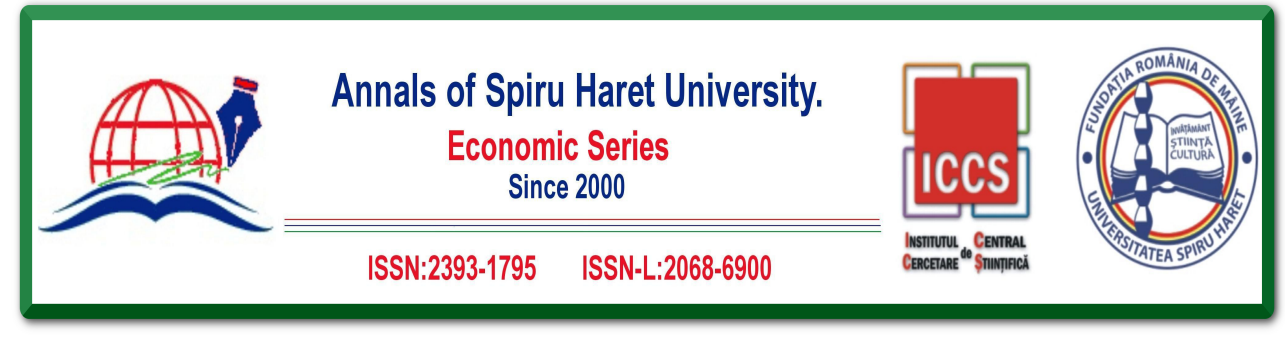

Issue 3/2019

[67] Tonges, M.C. (1998). "Job design for nurse case managers: Intended and unintended effects on satisfaction well-being." Nursing Case Management, 3 (1), 11-23.

[68] Trist, E.L. The Evolution of Socio-technical Systems. Toronto: Quality of Working Life Centre, 1981.

[69] Macy, B.A., \& Izumi, H. (1993). "Organizational change, design, and work innovation: A meta-analysis of 131 North American field studies: 1961-991." Research in Organizational Change and Development, 7, 235-313.

[70] Van de Ven, H.A., \& Ferry, D.L. Measuring and Assessing Organizations. New York: Wiley, 1980.

[71] Zareen, M., Razzaq, K., \& Muitaba, B.G. (2013). J"ob design and employee performance: The moderating role of employee psychological perception." European Journal of Business and Management, 5 (5), 46-55.

[72] Zeira, Y. (1974). "Job rotation for management development." Personnel, 51 (4), 25 35. 
